\title{
Clinical and prognostic features of cerebral toxoplasmosis in HIV infected patients - a case series
}

\author{
Andrei Vâțăa, ${ }^{1,2}$, Carmen Manciuc ${ }^{1,2}$, Cristina Nicolau ${ }^{1,2}$, Liviu Prisacariu ${ }^{1,2}$, Carmen Dorobăț ${ }^{1,2}$ \\ From The 9th Edition of the Scientific Days of the National Institute for Infectious Diseases Prof Dr Matei Bals \\ Bucharest, Romania. 23-25 October 2013
}

\section{Background}

Although cerebral toxoplasmosis incidence has declined as a result of antiretroviral treatment (ART), it still is a serious diagnostic and therapeutic problem and a lifethreatening condition.

\section{Methods}

We performed a retrospective study of the medical charts of patients diagnosed with cerebral toxoplasmosis admitted to the Infectious Diseases Hospital of Iaşi in the last 5 years (2008-2012).

\section{Results}

Cerebral toxoplasmosis led to the diagnosis of HIV infection in 3/11 patients, and was the AIDS defining disease in $2 / 11$ cases. Most of the patients (9/11) belonged to the historical 1989 cohort; the mean age was 22.5 years, 6/11 were males. The mean CD4+ cell count was 26.7 cells/cmm (95\%CI: 5.5-49.7); all the patients were viremic at the time of diagnosis (mean viral load: $1.21 \times 10^{5}$ copies $/ \mathrm{mL}$ ). The clinical manifestations varied, ranging from mild persistent headache to coma. Neurologic manifestations were seen in $7 / 11$ of cases, $5 / 11$ had convulsions. All patients were seropositive for IgG antibody against Toxoplasma gondii in blood, but only $5 / 11$ had high titers ( $>300 \mathrm{UI} / \mathrm{mL}$ ). Cerebral imaging studies (6 CT and 5 IRM) were performed and showed suggestive lesions in all cases. 7/11 patients were receiving ART before diagnosis, and 6/11 had recommendations for co-trimoxazole prophylaxis, but most of them had a low adherence the treatment. Co-trimoxazole was the main anti-toxoplasma drug in all cases; clindamycin or clarithromycin were sometimes associated (2/11).

\footnotetext{
* Correspondence: andreiandrei@yahoo.com

"Gr.T.Popa" University of Medicine and Pharmacy, Iaşi, Romania

Full list of author information is available at the end of the article
}

4/11 patients died, three of them being newly discovered, late presenter HIV cases. 2 patients had relapses and 4/11 neurological sequelae.

\section{Conclusion}

Cerebral toxoplasmosis is a rare but serious opportunistic infection, seen more frequently in severely immunocompromised, non-adherent patients, but it can be sometimes seen in previously apparently healthy individuals.

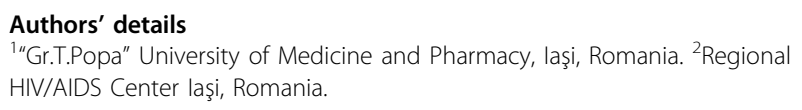

Authors' details

"Gr.T.Popa" University of Medicine and Pharmacy, laşi, Romania. ${ }^{2}$ Regional HIV/AIDS Center laşi, Romania.

Published: 16 December 2013

doi:10.1186/1471-2334-13-S1-P10

Cite this article as: Vâță et al:: Clinical and prognostic features of cerebral toxoplasmosis in HIV infected patients - a case series. BMC Infectious Diseases 2013 13(Suppl 1):P10.

Submit your next manuscript to BioMed Central and take full advantage of:

- Convenient online submission

- Thorough peer review

- No space constraints or color figure charges

- Immediate publication on acceptance

- Inclusion in PubMed, CAS, Scopus and Google Scholar

- Research which is freely available for redistribution
C Biomed Central

C 2013 Andrei et al; licensee BioMed Central Ltd. This is an Open Access article distributed under the terms of the Creative Commons Attribution License (http://creativecommons.org/licenses/by/2.0), which permits unrestricted use, distribution, and reproduction in any medium, provided the original work is properly cited. 